\title{
PENGEMBANGAN APLIKASI SISTEM INFORMASI PRAKERIN BERBASIS ANDROID DI JURUSAN ELEKTRONIKA INDUSTRI SMKN 1 CIKANDE
}

\author{
Muhammad Amir Baihaqi ${ }^{1}$, Didik Aribowo ${ }^{2}$, Mustofa Abi Hamid ${ }^{3}$ \\ ${ }^{1,2,3}$ Program Studi Pendidikan Vokasional Teknik Elektro, Fakultas Keguruan dan Ilmu Pendidikan, Universitas Sultan \\ Ageng Tirtayasa \\ Email: baihaqim67@gmail.com
}

\begin{abstract}
This study aims to produce a product in the form of an Android-based apprenticeship information system in the Department of Electronics Industry, Vocational Secondary School (SMK) Negeri 1 Cikande. The development model used is a Waterfall with a software development method that has four stages: (1) Systems Analysis, (2) Design, (3) Programming, and (4) Testing. The test subjects consisted of 2 teachers and 24 students with data collection techniques in the form of literature and questionnaire studies. Media expert data collection has two aspects, namely: visual appearance and communication, while the user contains three points, including accuracy, visual communication, and data input. The results of user trial through questionnaires distributed to teachers obtained a value of $78.7 \%$ and students at $79.86 \%$ can be declared feasible. The implication of the results of this study is an Android application that is used by teachers, supervisors, and students for industrial work activities in the Department of Electronics Industry, SMK Negeri 1 Cikande, to make it faster, easier, and more efficient in conducting the internship process.
\end{abstract}

Keywords: Implications, Research and Development, Trial Results, Waterfall.

\begin{abstract}
ABSTRAK
Penelitian ini bertujuan menghasilkan produk berupa sistem informasi prakerin berbasis Android di Jurusan Elektronika Industri SMK Negeri 1 Cikande. Model pengembangan yang digunakan ialah Waterfall dengan metode pengembangan software yang memiliki empat tahapan: (1) Analisis Sistem, (2) Desain, (3) Pemrograman, dan (4) Uji coba. Subjek uji coba berjumlah 2 guru beserta 24 siswa dengan teknik pengumpulan data berupa studi pustaka dan kuisioner. Pengumpulan data ahli media memiliki dua aspek yaitu tampilan dan komunikasi visual, sedangkan pengguna berisi tiga aspek diantaranya akurasi, komunikasi visual, dan penginputan data. Hasil ujicoba pengguna melalui kuesioner yang disebarkan kepada guru memperoleh nilai sebesar 78,7\% dan siswa sebesar 79,86\% sehingga dapat dinyatakan layak. Implikasi dari hasil penelitian ini ialah sebuah aplikasi Android yang dimanfaatkan oleh guru, pembimbing, dan siswa untuk kegiatan prakerin di Jurusan Elektronika Industri SMK Negeri 1 Cikande, agar lebih cepat, mudah, dan efisien dalam melakukan proses prakerin.
\end{abstract}

Kata kunci: Hasil Uji Coba, Implikasi, Research and Development, Waterfall.

\section{PENDAHULUAN}

Era ICT dan revolusi industri 4.0 telah menjadi komponen penting dalam kehidupan kita, Salah satunya handphone telah menjadi tren dengan sebutan smartphone hadir sebagai sebuah teknologi multifungsi yang dapat mempermudah kehidupan manusia (Ristekdikti, 2018).

Salah satu perubahan lingkungan yang sangat mempengaruhi dunia pendidikan adalah hadirnya teknologi informasi. Teknologi Informasi dan Komunikasi merupakan elemen penting dalam kehidupan berbangsa dan bernegara. Peranan teknologi informasi pada aktivitas manusia saat ini memang begitu besar. Teknologi informasi telah menjadi fasilitas utama bagi kegiatan berbagai sektor kehidupan dimana memberikan andil besar terhadap perubahan-perubahan yang mendasar pada struktur operasi dan manajemen organisasi, 
pendidikan, transportasi, kesehatan, dan penelitian (Gani, 2016).

Peran teknologi informasi dalam pendidikan sangatlah diperlukan saat ini seperti menjadi sarana informasi yang up-to-date. Selain dapat membantu siswa dalam belajar juga memiliki peran yang cukup berpengaruh bagi guru, terutama dalam penggunaan fasilitas demi memperkaya kemampuan mengajar (Budiman, 2017). Administrasi didefinisikan sebagai keseluruhan proses kerjasama antara dua orang manusia atau lebih yang didasarkan atas rasionalitas tertentu untuk mencapai tujuan yang telah ditentukan sebelumnya dimana saat ini menjadi hal utama dalam pendidikan (Nuari, 2014).

Sekolah Menengah Kejuruan (SMK) tidak dapat lepas dari pengaruh kemajuan teknologi pada saat ini (Sukir, Nurkhamid, \& Nurdiyansyah, 2019). Disebuah SMK, siswa melakukan banyak praktikum untuk meningkatkan kemampuan yang sesuai dengan bidangnya masing-masing, agar kelak cepat terserap di lapangan pekerjaan. Siswa akan melaksanakan kegiatan program sekolah yang bersinergi langsung dengan industri yakni PRAKERIN (Praktek Kerja Industri) guna mengukur keterampilan dan kompetensi siswa saat praktikum.

SMK selalu terikat dengan pengasahan kompetensi siswa pada tiap bidangnya di internal sekolah maupun eksternal seperti halnya prakerin. Hal itu tentu memliki proses yang panjang mulai dari bimbingan peminatan, rekomendasi tempat, pengajuan ke perusahaan, agenda kegiatan, hingga penulisan laporan.

Umumnya dalam melaksanakan prakerin, siswa akan menjalani proses pembimbingan dengan seorang atau lebih pembimbing yang memiliki kompetensi terkait dengan bidang penelitian yang akan dikerjakan. Model pembimbingan konvensional masih memiliki banyak kendala dalam prakteknya, seperti kesulitan dalam pengaturan waktu proses bimbingan, proses pencatatan perkembangan kegiatan penelitian yang tidak dilakanakan dengan konsisten. Sehingga hal ini berdampak pada terhambatnya proses pengerjaan prakerin (Nugroho, 2016: 2087-0256).

Tempat prakerin adalah perusahaan atau instansi yang bekerjasama dengan sekolah/kampus. Perusahaan maupun tempat magang hanya dapat menerima peserta magang paling banyak 30\% dari jumlah karyawan, dengan mengorganisasi kegiatan prakerin secara rapi antara peserta dan perusahaan/intansi tempat magang maka semua pihak dapat merasakan manfaat dari kegiatan prakerin (Arifin, 2014). Melalui sistem informasi yang dikembangkan secara modern dengan menyajikan info - info real-time update seputar prakerin dapat diolah menjadi sebuah aplikasi penggerak login melalui Android.

Maka dari itu berdasarkan pada pengambilan data awal sebanyak $97,61 \%$ siswa membutuhkan sistem informasi yang up-to-date agar mengatasi permasalahan kurangnya informasi yang didapat siswa secara cepat. Dengan rincian $47,61 \%$ responden siswa menginginkan sistem informasi online untuk prakerin daripada pembayaran SPP, Penilaian, Konsultasi BP ataupun perihal absensi. Keinginan siswa ini disebabkan $11,9 \%$ siswa jarang mengetahui prosedur - prosedur, 14,28\% kurang mengetahui industri - industri yang terkait, $30,95 \%$ siswa saat prakerin berlangsung mengalami miskomunikasi, dan $45,32 \%$ siswa tidak mengetahui batas masa prakerin hingga sulit melakukan pengarsipan laporan dan nilai ketika prakerin telah selesai dilaksanakan.

Kemudian dalam survei pengambilan data awal, platform Android lebih dominan dibutuhkan siswa dengan $64,28 \%$ daripada media cetak $11,9 \%$ ataupun website $23,9 \%$. Aplikasi sistem informasi ini dibuat dengan menggunakan software Android Studio dan untuk Jurusan Elektronika Industri SMK Negeri 1 Cikande.

Pengembangan aplikasi sistem informasi prakerin berbasis Android ini dikaji dengan 
penelitian relevan yang memiliki tema yang berkaitan dengan beberapa penelitian sebelumnya. Hal ini guna menjadi acuan terhindar dari duplikasi penelitian, diantaranya :

Pertama, Pengembangan SI Manajemen Skripsi di Jurusan Teknik Elektro, FT UNESA oleh Yuni Yamasari, dkk. (2015). Sistem informasi ini mengintegrasikan beberapa modul yang berkaitan dengan skripsi berupa: manajemen proposal, manajemen data skripsi, manajemen penjadwalan ujian proposal, dan laporan, monitoring, serta informasi yang berkaitan dengan skripsi (prosedur, aturan, dan sanksi, serta panduan skripsi) sehingga permasalahan skripsi dapat diselesaikan dan pelayanan dapat dioptimalkan (Yamasari, dkk 2015: 1-10).

Terakhir, Rancang Bangun Sistem Informasi Prakerin oleh Silvia Rizka Febriyanti \& Lusi Melian (2013). Sistem informasi ini mempermudah pengelolaan data peserta prakerin baik dari segi penerimaan, penjadwalan, absensi maupun penilaian (Febriyanti \& Melian, 2013).

Berdasarkan referensi di atas dapat ditarik kesimpulan bahwa sistem informasi sebelumnya terdapat beberapa fitur yang masih dapat dikembangkan seperti menu berita yang up-to-date, absensi, dan jurnal harian siswa, wadah arsip laporan, hingga penilaian akhir prakerin. Semua menu tersebut menjadi fiturpembeda yang dikembangkan dalam aplikasi sistem informasi prakerin bebasis Android ini.

\section{METODE}

Model pengembangan sistem yang digunakan dalam rancang bangun Sistem Informasi prakerin berbasis Android ini menggunakan model Waterfall atau model sekuensial linier. Model Waterfall merupakan model yang paling tua dan yang paling banyak digunakan untuk rekayasa perangkat lunak. Model Waterfall merupakan model pengembangan perangkat lunak yang sistematik dan sekuensial yang mulai pada tingkat dan kemajuan sistem sampai pada analisis, desain, kode, dan tes (Pressman, 2002).

Metode Waterfall dipilih karena tahapan dalam pengembangan perangkat lunak mudah dipahami dan memiliki struktur alur yang urut dan sistematis (Andayani \& Dirawan, 2019).

Prosedur pengembangan yang dilakukan untuk menghasilkan produk tertentu dan untuk menguji kelayakan produk ditunjukan pada Gambar 1 berikut:

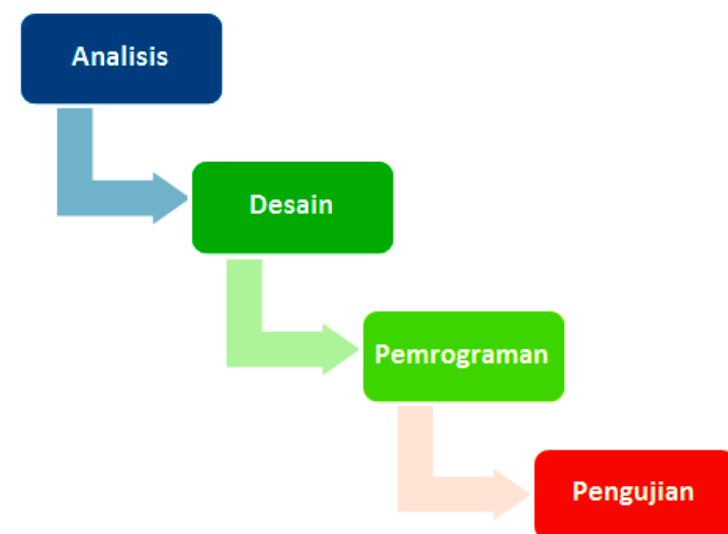

Gambar 1. Model Waterfall

Analisis sistem untuk memahami sifat program yang akan dibangun, perekayasa perangkat lunak (analisis) harus memahami domain informasi, tingkah laku, unjuk kerja, dan antarmuka yang diperlukan. Analisis kebutuhan perangkat lunak merupakan proses pengumpulan kebutuhan yang dapat dilakukan secara terus menerus sehingga dapat merincikan kebutuhan perangkat lunak yang akan di rancang (Susafa'ati, 2019). Analisis kebutuhan software merupakan proses pengumpulan informasi. Informasi yang dikumpulkan adalah informasi yang dapat diterjemahkan ke dalam data, arsitektur, antarmuka dan komponen untuk mendukung aktivitas-aktivitas selanjutnya. Untuk mempermudah pada proses pembuatan aplikasi, maka dapat digunakan Framework.

Framework atau dalam Bahasa Indonesia kerangka kerja adalah sebuah software untuk memudahkan para programmer untuk membuat aplikasi atau web yang isinya adalah berbagai 
fungsi, plugin dan konsep sehingga membentuk suatu sistem tertentu. Dengan menggunakan Framework, sebuah aplikasi akan terstruktur dan tersusun dengan rapi (Pressman, 2010).

Desain sistem merupakan proses multi langkah yang berfokus pada empat atribut sebuah program yang berbeda yaitu struktur data, asitektur perangkat lunak, representasi antarmuka, dan detail algoritma prosedural. Proses desain menerjemahkan kebutuhan ke dalam sebuah representasi perangkat lunak yang dapat diperkirakan demi kualitas sebelum proses coding dimulai. Tahap ini pun mentranslasi kebutuhan perangkat lunak dari tahap analisis kebutuhan ke representasi desain agar dapat diimplementasikan menjadi program pada tahap selanjutnya. Desain perangkat lunak yang dihasilkan pada tahap ini juga perlu didokumentasikan (Dini \& Agmawarnida, 2018).

Untuk pengembangan sistem digunakan Data Flow Diagram (DFD) sebagai media untuk menjelaskan semua alur data beserta proses-proses yang terdapat didalam sistem. Berikut ini DFD dari aplikasi sistem informasi:

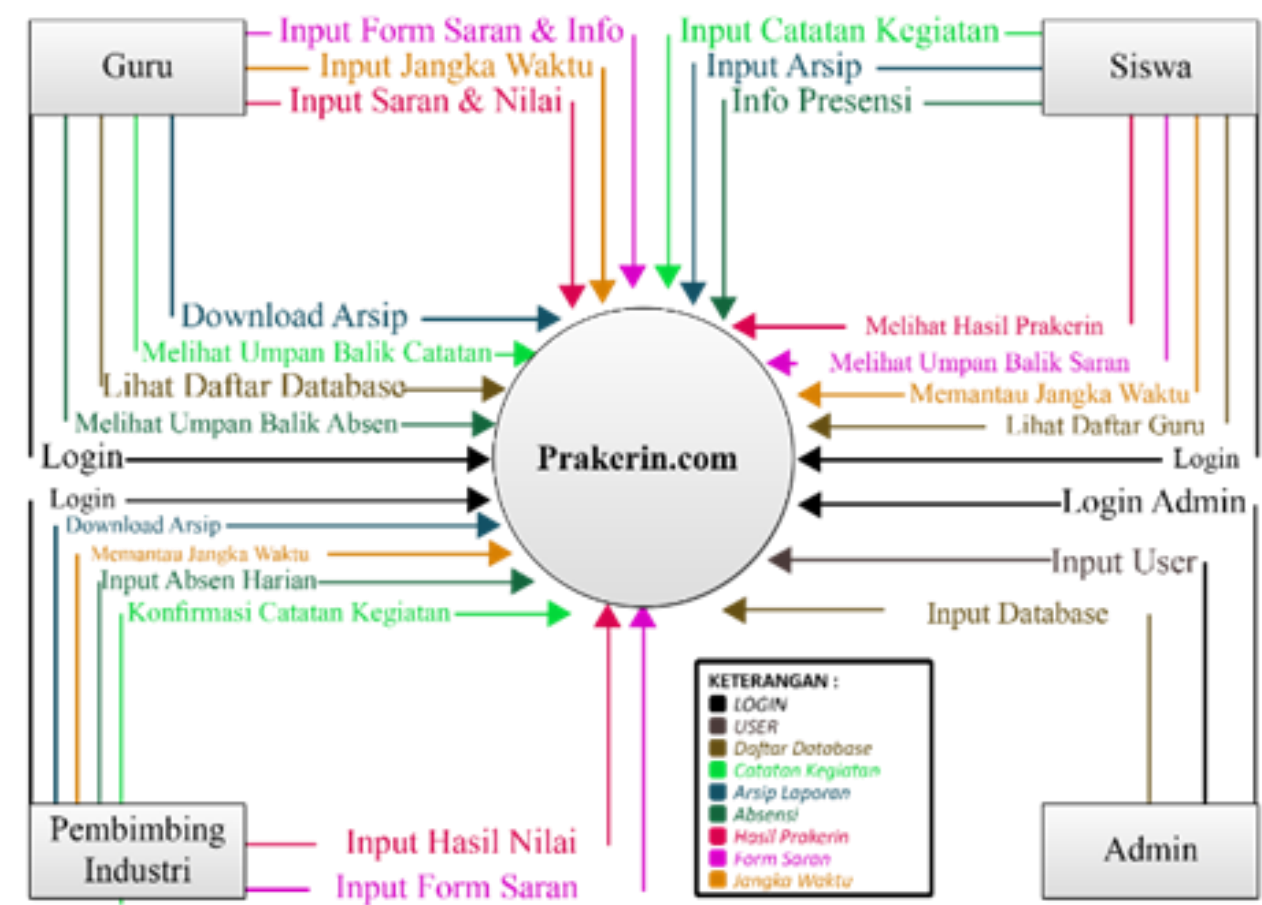

Gambar 2. Data Flow Diagram

Sedangkan representasi dari bentuk software dijabarkan dalam tahap-tahap pembuatan flowchart, stroryboard, penetapan konten, dan penyusunan konten.

Desain ujicoba produk terbagi menjadi dua yaitu desain \& subjek ujcoba. Dimana desain ujicoba sebelum diujicobakan produk mengenai sistem informasi prakerin ini dilakukan validasi terlebih dahulu oleh ahli media kemudian dilakukan tahap revisi dan diujicobakan kepada pengguna sebagai subjek ujicoba. Subjek ujicoba terdiri dari dua guru beserta 24 siswa Jurusan Elektronika Industri.

Teknik pengumpulan data yang digunakan yaitu (1) Studi pustaka yang diperoleh dari buku ilmiah, karya tulis ilmiah, peraturan-peraturan, ketetapan-ketetapan, dan sumber-sumber tertulis baik tercetak maupun elektronik lain dan (2) Angket kuisioner yang dengan berjenis tertutup yang digunakan untuk menguatkan kesimpulan penelitian.

Instrumen pengumpulan data yang digunakan terbagi dua yakni berupa (1) Ahli 
media yang memiliki dua aspek diantaranya tampilan dan komunikasi visual serta (2) Pengguna berisi tiga aspek diantaranya akurasi, komunikasi visual, dan penginputan data. Dilakukan pengujian instrumen sebelum diserbarkan guna mengetahui tingkat validitas sekaligus menjadi syarat mutlak penelitian menjadi valid.

Teknik analisis data yang digunakan dalam penelitian ini adalah teknik analisis deskriptif. Teknik analisis deskriptif digunakan dengan menggunakan statistik deskriptif (Manfaat, 2018).

\section{HASIL DAN PEMBAHASAN}

Pengembangan aplikasi dimulai dari menganalisis permasalahan dan kebutuhan yang ada. Tahap analisis kebutuhan adalah tahap untuk mengidentifikasi apa saja yang diperlukan dan dibutuhkan oleh para pengguna (Ispandi, 2019).

Selanjutnya pembuatan flowchart pada aplikasi sistem informasi prakerin yang terdiri dari User guru, pembimbing, dan User siswa yang terdapat pada Gambar 3, 4, dan 5 .

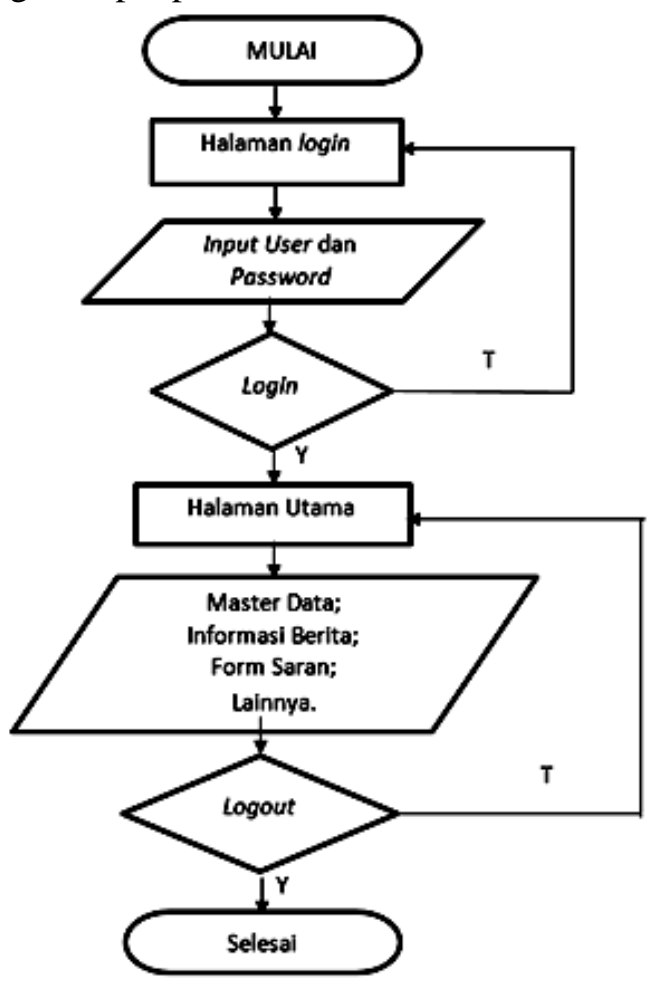

Gambar 3. Flowchart User Guru

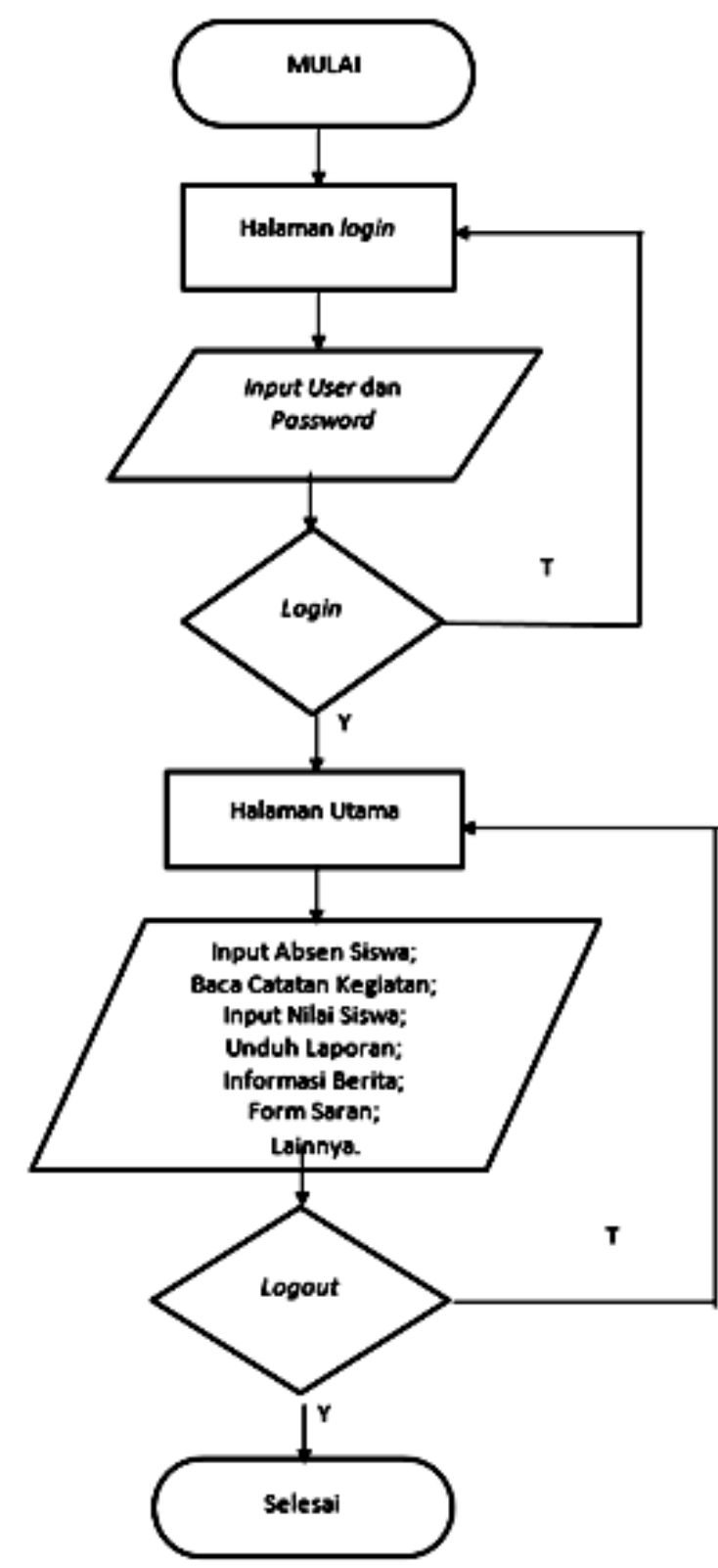

Gambar 4. Flowchart User Pembimbing 


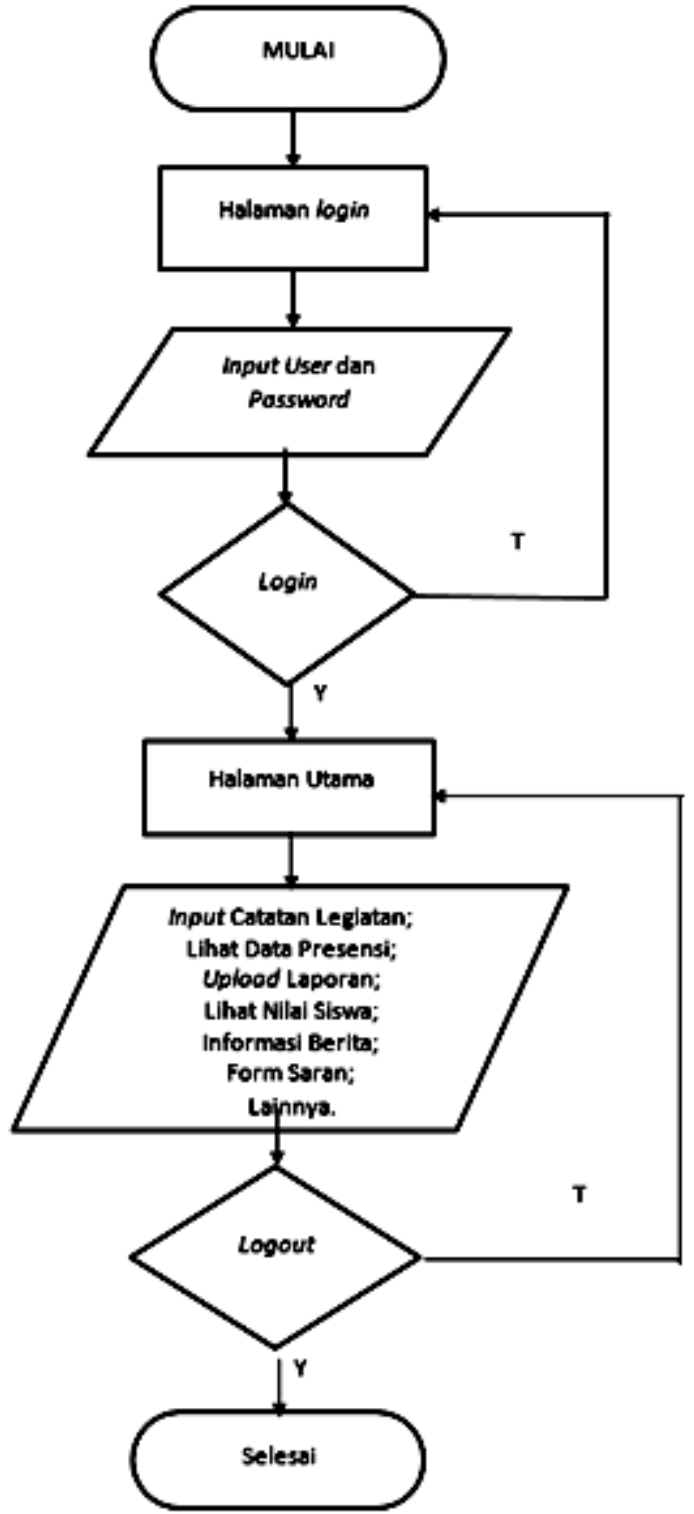

Gambar 5. Flowchart User Siswa

Selanjutnya pembuatan up-to-date yang merupakan suatu teknik yang mempelajari tentang perencanaan urutan suatu scene atau adegan berupa gambar visual untuk memudahkan perancang dalam membuat sebuah alur cerita (Pradana \& Nita, 2019). Upto-date pada aplikasi sistem informasi prakerin berbasis Android terdapat pada Gambar 6 .

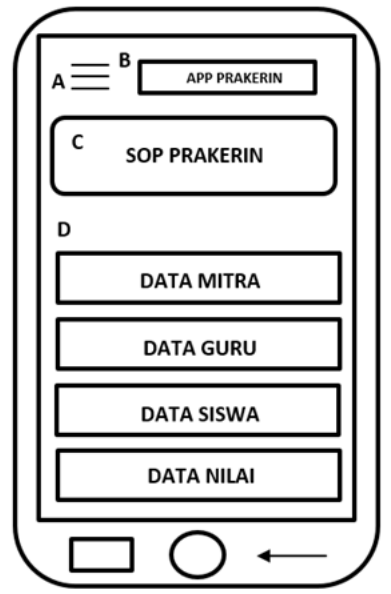

Gambar 6. Up-to-date Aplikasi Prakerin

Proses penetapan konten pada aplikasi sistem informasi prakerin berbasis Android ini ditentukan dengan angket pengambilan data awal, konsultasi pembimbing, dan wawancara Kasubag Hubungan Industri. Terdapat tiga User yang memiliki konten yang masing-masing berbeda pada setiap tampilannya. Penetapan konten User ditampilkan pada Gambar 7, 8, dan 9.

\begin{tabular}{|c|c|c|c|c|c|}
\hline \multicolumn{6}{|c|}{ User Guru } \\
\hline Data Mitra & $\begin{array}{l}\text { Data } \\
\text { Siswa }\end{array}$ & $\begin{array}{c}\text { Data } \\
\text { Absen }\end{array}$ & Data Nilai & Catatan & Data Arsip \\
\hline $\begin{array}{c}\text { Daftar } \\
\text { Industri } \\
\text { yang } \\
\text { Bekerjasama }\end{array}$ & $\begin{array}{c}\text { Daftar } \\
\text { nama } \\
\text { siswa yang } \\
\text { sudah } \\
\text { mendaftar } \\
\text { prakerin }\end{array}$ & \multirow{3}{*}{$\begin{array}{c}\text { Daftar } \\
\text { absensi } \\
\text { prakerin } \\
\text { harian } \\
\text { siswa }\end{array}$} & $\begin{array}{c}\text { Daftar nama } \\
\text { siswa yang } \\
\text { telah selesai } \\
\text { prakerin }\end{array}$ & $\begin{array}{c}\text { Daftar } \\
\text { nama } \\
\text { siswa } \\
\text { yang } \\
\text { sedang } \\
\text { prakerin }\end{array}$ & $\begin{array}{c}\text { Daftar } \\
\text { laporan } \\
\text { yang telah } \\
\text { di-upload } \\
\text { siswa }\end{array}$ \\
\hline $\begin{array}{c}\text { Daftar } \\
\text { Siswa yang } \\
\text { terdaftar } \\
\text { prakerin }\end{array}$ & $\begin{array}{c}\text { Masa } \\
\text { prakerin, } \\
\text { Informasi }\end{array}$ & & \multirow{2}{*}{$\begin{array}{c}\text { Penginputan } \\
\text { nilai } \\
\text { prakerin } \\
\text { siswa }\end{array}$} & \multirow{2}{*}{$\begin{array}{c}\text { Melihat } \\
\text { catatan } \\
\text { harian } \\
\text { siswa }\end{array}$} & \multirow{2}{*}{$\begin{array}{c}\text { Mengunduh } \\
\text { hasil } \\
\text { laporan } \\
\text { prakeirn } \\
\text { siswa }\end{array}$} \\
\hline $\begin{array}{c}\text { Masa } \\
\text { prakerin \& } \\
\text { Informasi } \\
\text { profil siswa }\end{array}$ & $\begin{array}{l}\text { siswa \& } \\
\text { Tempat } \\
\text { prakerin }\end{array}$ & & & & \\
\hline
\end{tabular}

Gambar 7. Penetapan Konten User Guru

\begin{tabular}{|c|c|c|c|}
\hline \multicolumn{4}{|c|}{ User Pembimbing } \\
\hline Absen Siswa & $\begin{array}{l}\text { Data Arsip } \\
\text { Siswa }\end{array}$ & Data Nilai Siswa & Catatan Siswa \\
\hline $\begin{array}{c}\text { Daftar nama } \\
\text { siswa yang } \\
\text { terdaftar prakerin } \\
\text { di Perusahaan } \\
\text { tersebut }\end{array}$ & $\begin{array}{l}\text { Daftar laporan } \\
\text { yang telah di- } \\
\text { upload siswa }\end{array}$ & $\begin{array}{c}\text { Daftar nama } \\
\text { siswa yang telah } \\
\text { selesai prakerin }\end{array}$ & $\begin{array}{c}\text { Daftar catatan } \\
\text { harian siswa yang } \\
\text { telah diajukan }\end{array}$ \\
\hline \multirow{2}{*}{$\begin{array}{l}\text { Input absen } \\
\text { harian siswa }\end{array}$} & \multirow{2}{*}{$\begin{array}{l}\text { Mengunduh hasil } \\
\text { laporan prakeirn } \\
\text { siswa }\end{array}$} & \multirow{2}{*}{$\begin{array}{c}\text { Penginputan nilai } \\
\text { prakerin siswa }\end{array}$} & $\begin{array}{c}\text { Membaca catatan } \\
\text { harian siswa }\end{array}$ \\
\hline & & & $\begin{array}{l}\text { Meng-approve } \\
\text { catatan harian }\end{array}$ \\
\hline
\end{tabular}

Gambar 8. Penetapan Konten User Pembimbing 


\begin{tabular}{|c|c|c|c|}
\hline \multicolumn{4}{|c|}{ User Siswa } \\
\hline Data Guru & $\begin{array}{l}\text { Informasi } \\
\text { Presensi }\end{array}$ & $\begin{array}{l}\text { Catatan } \\
\text { Kegiatan }\end{array}$ & Data Arsip \\
\hline $\begin{array}{l}\text { Daftar nama guru } \\
\text { sekolah }\end{array}$ & \multirow[b]{2}{*}{$\begin{array}{c}\text { Melihat riwayat } \\
\text { absensi } \\
\text { kehadiran } \\
\text { prakerin }\end{array}$} & $\begin{array}{c}\text { Membuat } \\
\text { catatan harian }\end{array}$ & \multirow[b]{2}{*}{$\begin{array}{l}\text { Mengupload laporan } \\
\text { hasil prakerin }\end{array}$} \\
\hline $\begin{array}{c}\text { Informasi profil } \\
\text { guru }\end{array}$ & & $\begin{array}{c}\text { Menyimpan } \\
\text { catatan yang } \\
\text { telah dibuat } \\
\text { kepada } \\
\text { pembimbing }\end{array}$ & \\
\hline
\end{tabular}

Gambar 9. Penetapan Konten User Siswa
Setelah menetapkan konten kemudian konten yang sudah ada disusun dan dimasukan ke sistem informasi prakerin yang akan dirancang. Penyusunan konten ini dibagi menjadi tiga yaitu User guru, User pembimbing dan User siswa. Penyusunan konten User ditampilkan pada Gambar 10, 11, dan 12 berikut.

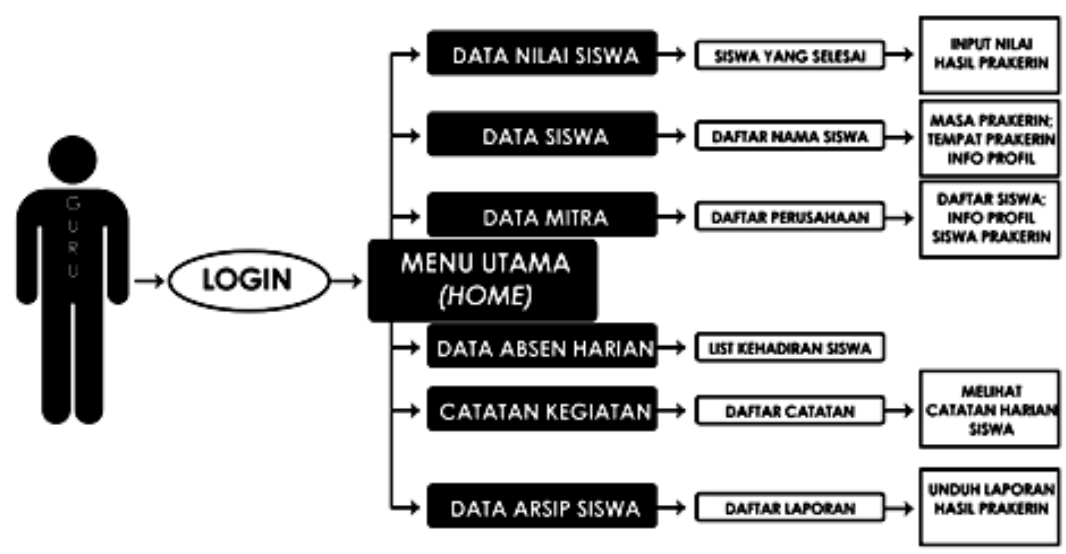

Gambar 10. Penyusunan Konten User Guru

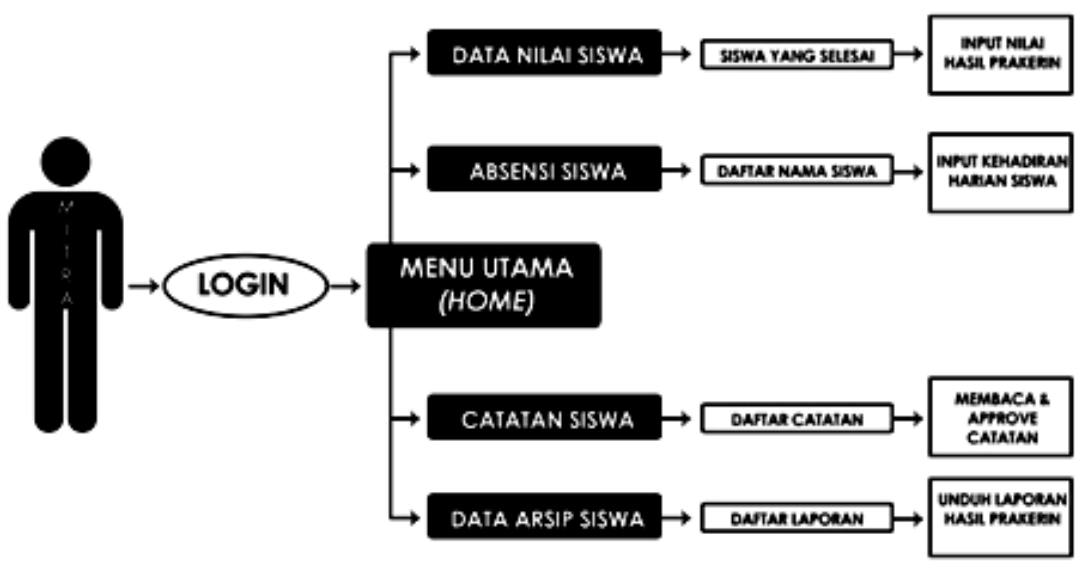

Gambar 11. Penyusunan Konten User Pembimbing

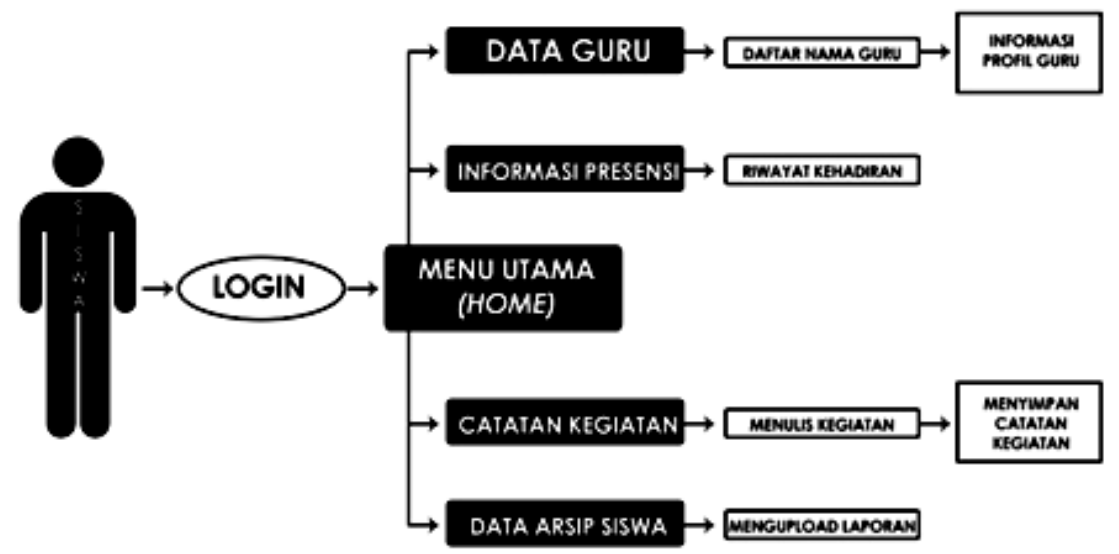

Gambar 12. Penyusunan Konten User Siswa 
Desain harus diterjemahkan ke dalam bentuk mesin yang dapat dibaca. Jika desain dilakukan dengan cara yang lengkap, maka pembuatan kode dapat diselesaikan secara mekanis. Kode untuk menerjemahkan data yang telah dirancang dalam bahasa pemrograman yang biasanya disebut dengan meng-coding. Coding adalah bahasa atau kode pemograman agar aplikasi dapat berjalan (Binus, 2018). Kode pun memiliki tahap persiapan yang bertujuan untuk memenuhi segala kebutuhan sebelum melakukan penulisan program. Persiapan yang dilakukan seperti pemilihan bahasa pemrograman, memilih text editor sebagai media penulisan program dan unit - unit penguji. Secara spesifik langkah-langkah dari tahap persiapan ialah meng-install beberapa software diantaranya XAMPP, Sublime Text, Android Studio, dan Browser.

Tahap selanjutnya yakni pemrograman atau kegiatan mengimplementasikan algoritma yang digunakan. Program tampilan halaman login ditunjukkan pada Gambar 13.

\begin{tabular}{|c|}
\hline $\begin{array}{l}\text { package coder.kerja.praktek; } \\
\text { import... } \\
\text { public class ActivityLogin extends AppCompatActivity \{ } \\
\text { Toolbar toolbar; } \\
\text { EditText username,password; } \\
\text { CheckBox checkBox; } \\
\text { Button login; } \\
\text { private View parent_view; } \\
\text { ProgressDialog progressDialog = null; } \\
\text { JSONReader j_reader; } \\
\text { CommonClass common; } \\
\text { private static CheckBox show_hide_password; } \\
\text { SharedPreferences userPref; } \\
\text { private static Animation shakeAnimation; } \\
\text { private static LinearLayout loginLayout; } \\
\text { private static View view; } \\
\text { private TextView login_hp; } \\
\text { @Override } \\
\text { protected void onCreate(Bundle savedInstanceState) \{ } \\
\text { super.onCreate(savedInstanceState); } \\
\text { set_ContentView(R.layout.activity_login); } \\
\text { j_reader = new JSONReader(this); } \\
\text { common_ = new CommonClass(this); } \\
\text { userPref = } \\
\text { PreferenceManager.getDefaultSharedPreferences(ActivityLLogin.this); } \\
\text { show_hide_password = findViewById(R.id.show_hide_password); } \\
\text { username = findViewById(R.id.username); } \\
\text { password = findViewById(R.id.password); }\end{array}$ \\
\hline
\end{tabular}

Gambar 13. Contoh Kode Login

Pengujian sistem berfokus pada dua hal. Pertama logika internal perangkat lunak untuk memastikan bahwa semua pernyataan sudah diuji dan kedua pengujian pada eksternal fungsional untuk menemukan kesalahankesalahan dan memastikan bahwa masukan akan memberikan hasil yang aktual sesuai dengan hasil yang dibutuhkan. Pengujian sistem adalah tahapan yang dilakukan ketika sistem sudah disetujui termasuk program, menu ataupun konten yang telah dibuat pada tahap perancangan agar siap untuk dioperasikan. Tahap pengujian ini merupakan tujuan perancangan aplikasi sistem informasi prakerin berbasis Android di Jurusan Teknik Elektronika Industri SMK Negeri 1 Cikande.

Subjek ujicoba produk pengembangan sistem informasi prakerin Jurusan Elektronika Industri SMK Negeri 1 Cikande dengan materi interaksi manusia dan lingkungan yaitu beberapa siswa dengan pemilihan subjek ujicoba dilakukan kepada kelas XI, XII, dan guru wali kelas serta Kasubag Hubungan Industri.

Penelitian pengembangan sistem informasi prakerin berbasis Android bertujuan untuk mengembangkan sistem informasi prakerin yang ada di Jurusan Elektonika Industri SMK Negeri 1 Cikande dengan basis sistem operasi Android. Selain itu penelitian ini bertujuan untuk mengetahui tingkat kelayakan sistem informasi prakerin berbasis Android di Jurusan Elektronika Industri SMK Negeri 1 Cikande.

Kelayakan aplikasi ini dinilai dari validasi yang dilakukan oleh ahli media, pengguna guru, dan pengguna siswa. Untuk ahli media penilaian dilihat dari dua aspek yaitu aspek tampilan dan aspek kualitas teknis, sedangkan untuk pengguna dinilai dari tiga aspek yaitu aspek akurasi, aspek komunikasi visual, dan aspek penginputan data. Selain penilaian dari beberapa aspek tersebut terdapat juga saran yang digunakan untuk perbaikan produk sistem informasi praktek kerja industri berbasis Android ini.

Ahli media menilai bahwa sistem informasi perkuliahan ini sudah cukup baik dari segi tampilan, menu, dan item dari setiap menu yang mudah digunakan dan berfungsi dengan baik. Presentase yang didapatkan dari aspek 
tampilan ialah 94,44\% dikategori sangat layak. Dalam aspek kualitas teknis ahli media menilai menilai tata letak, menubar, sidebar yang sudah berfungsi dengan baik, namun terdapat error sedikit pada aplikasi. Presentase yang diperoleh dari aspek kualitas teknis ialah 93,17\% dengan katagori sangat layak. Hasil penilaian ahli media ditampilkan pada Tabel 1dan Gambar 14.

Tabel 1. Hasil Penilaian Ahli Media

\begin{tabular}{lcccc}
\hline No & Validator & Tampilan & Kualitas Teknis & Skor Total \\
\hline 1 & Ahli Media 1 & $94 \%$ & $88 \%$ & \\
2 & Ahli Media 2 & $94 \%$ & $97 \%$ & \\
\hline & Rerata Skor & $94 \%$ & $93 \%$ & $93 \%$ \\
\hline \multicolumn{2}{c}{ Kategori } & Sangat Layak & Sangat Layak & Sangat Layak \\
\hline
\end{tabular}

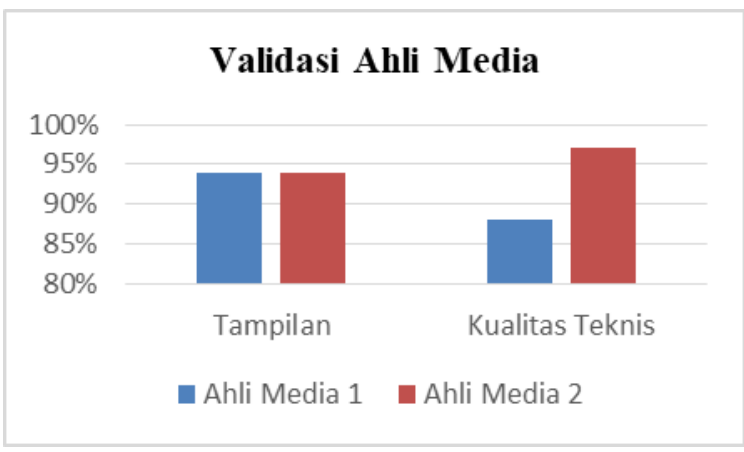

Gambar 14. Diagram Batang Validasi Media

Setelah proses uji kelayakan oleh ahli media selesai dan dinyatakan layak untuk digunakan. Kemudian dilakukan proses uji coba pengguna oleh guru dan siswa dengan hasil yang ditampilkan pada Gambar 15 berikut.

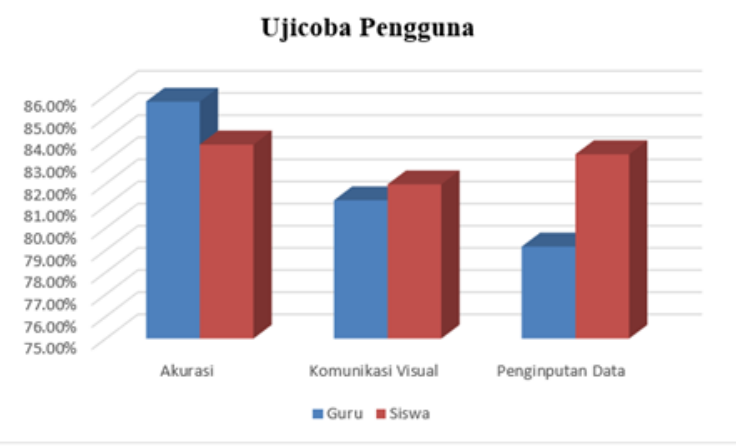

Gambar 15. Diagram Batang Uji Coba Pengguna

Berdasarkan Gambar 15 ditunjukkan bahwa aspek akurasi mendapatkan nilai $85,71 \%$ oleh guru dan $83,77 \%$ dari siswa. Kemudian aspek komunikasi visual memperoleh nilai presentase $81,25 \%$ oleh guru dan $81,97 \%$ dari siswa. Dan aspek yang terakhir yakni penginputan data memperoleh nilai sebesar $79,16 \%$ oleh guru dan $83,33 \%$ didapat dari siswa.

Produk sistem informasi prakerin berbasis Android yang telah dikembangkan terdiri dari tampilan awal sampai menu data nilai. Pada tampilan Awal, setelah User memiliki akun maka selanjutnya login dengan mamasukkan Username dan password yang telah terdaftar. Untuk siswa menggunakan NIS sedangkan guru menggunakan NIP/NUPTK, dan pembimbing industri menggunakan nomor telepon.

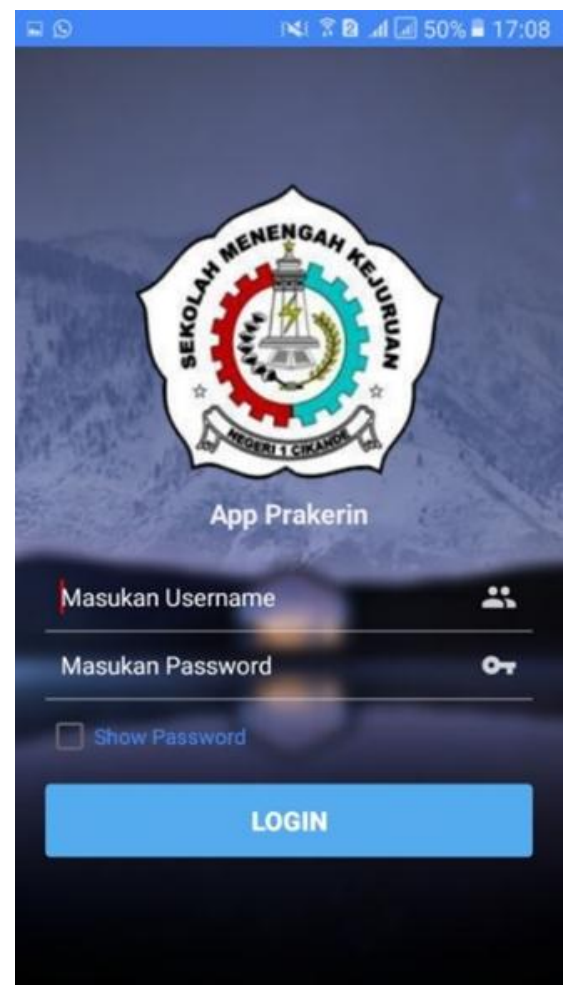

Gambar 16. Tampilan Login 
Pada tampilan halaman utama setiap User akan memiliki tampilan-tampilan yang berbeda, jika User guru terdapat papan informasi, shortcut menu berupa data berita, data siswa, data mitra, catatan siswa, absensi siswa, dan data arsip. Kemudian untuk User pembimbing industri terdapat papan informasi, shortcut menu berupa data berita, catatan siswa, absensi siswa, dan data arsip. Pada User siswa terdapat notifikasi kehadiran, papan informasi, shortcut menu berupa data guru, data berita, catatan kegiatan, informasi presensi, dan data arsip. Tampilan halaman utama pada aplikasi sistem informasi prakerin dapat dilihat pada Gambar 17.

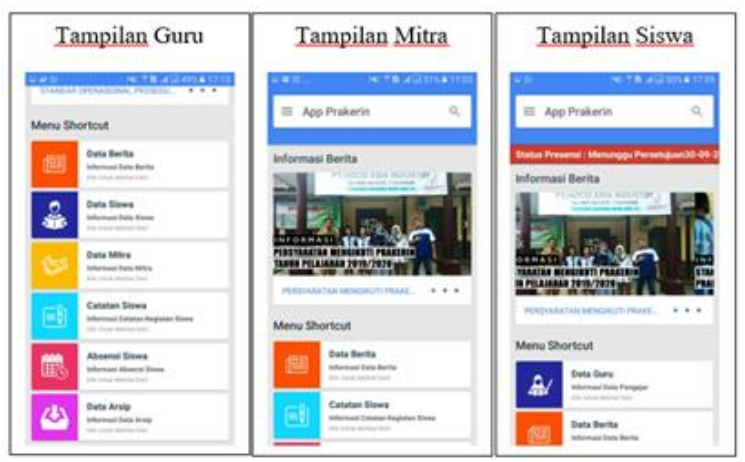

Gambar 17. Tampilan Menu Utama

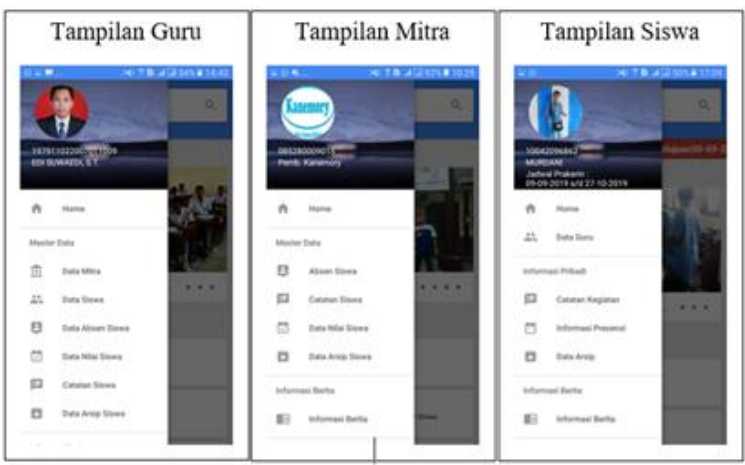

Gambar 18. Tampilan Sidebar Menu

Gambar 18 menunjukkan tampilan dari Sidebar Menu. Pada tampilan sidebar menu dapat dijelaskan bahwa pada master data tampilan User guru terdapat data mitra, data siswa, data absen siswa, data nilai siswa catatan siswa, dan data arsip siswa. Sedangkan pada master data tampilan User mitra lebih spesifik diantaranya absen siswa, catatan siswa, data nilai siswa, dan data arsip siswa. Pada master data tampilan User siswa lebih mengerucut dan spesifik yang diantaranya terdapat catatan kegiatan, informasi presensi, dan data arsip siswa.

Menu presensi merupakan salah satu fitur yang utama dimana salah satu permasalahan yakni kehadiran siswa selama praktek kerja industri berlangsung. Diharapkan melalui fitur ini akan meminimalisir manipulasi kehadiran siswa saat di perusahaan tempat prakerin. Tampilan menu presensi dapat dilihat pada Gambar 19.

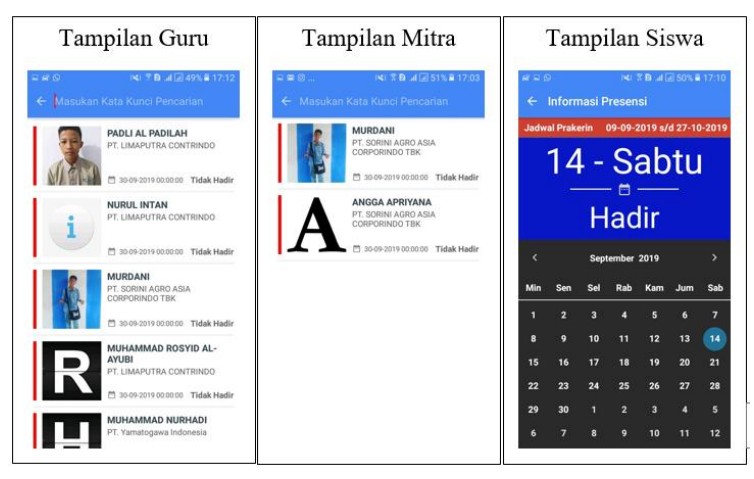

Gambar 19. Tampilan Menu Presensi

Fitur menu presensi memiliki fungsi yang berbeda pada masing-masing Usernya. Mulai dari mitra yang memiliki kewenangan untuk memberikan presensi harian kepada siswa kemudian status siswa berubah antara hadir, sakit, izin, dan sebagainya. Konten ini bertujuan agar guru dapat memantau siswa dari kejauhan dengan data presensi yang valid dan tentu upto-date.

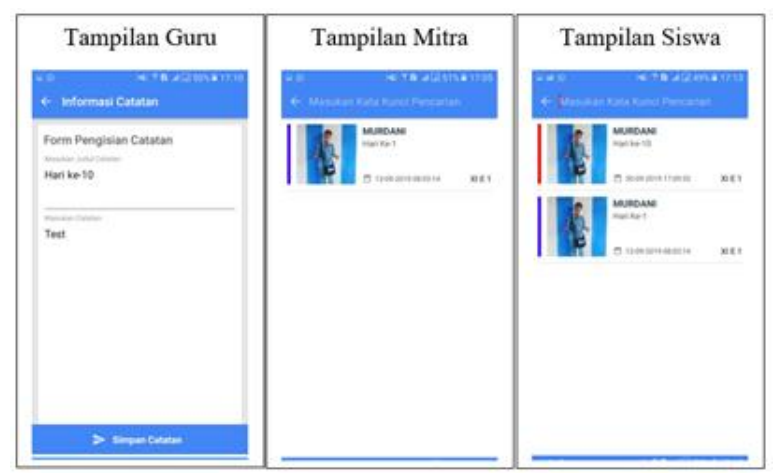

Gambar 20. Tampilan Menu Catatan

Gambar 20 menunjukkan tampilan menu catatan. Pada menu catatan kegiatan, User siswa bertugas untuk membuat jurnal harian 
selama prakerin berlangsung yang akan diajukan kepada pembimbing industri melalui fitur ini. Kemudian apabila jurnal telah dibuat dan disimpan oleh siswa, pembimbing industri berhak membaca dan menyetujui. Pembimbing industri dapat menjyetujui apabila catatan yang dibuat siswa telah valid dan relevan dalam kegiatan prakerin. Sedangkan dalam fitur ini guru bertugas memonitor kegiatan siswa ditiap harinya setelah catatan yang diajukan siswa pada pembimbing sudah dibaca dan disetujui. Hal ini berguna agar saling berkesinambungan antara kehadiran siswa dengan jurnal harian serta untuk menjadi evaluasi kegiatan prakerin agar lebih berkualitas.

Menu data arsip berfungsi sebagai wadah database dari surat, laporan atau sejenisnya dalam proses praktek kerja industri. Keterangan file yang dapat diunggah hanyalah yang berformat extension PDF. Cara pengaplikasiannya yaitu pada User siswa merupakan sebagai peng-upload file laporan setelah masa prakerin selesai agar diunduh kemudian dibaca oleh guru serta pembimbing industri sebagai bahan review pemberian nilai akhir prakerin kepada siswa tersebut. Tampilan menu arsip ditunjukkan pada Gambar 21.

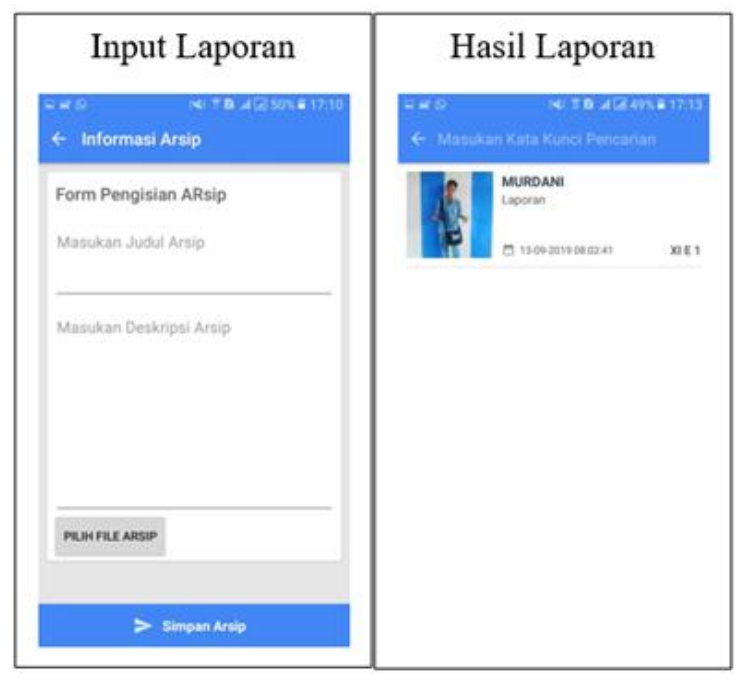

Gambar 21. Tampilan Menu Arsip

Menu data nilai merupakan fitur akhir dari semua proses prakerin siswa yang telah dilaksanakan. Siswa akan memperoleh nilai dari hasil kinerja selama praktek kerja industri berlangsung. Menu data nilai ditunjukkan pada gambar 22.

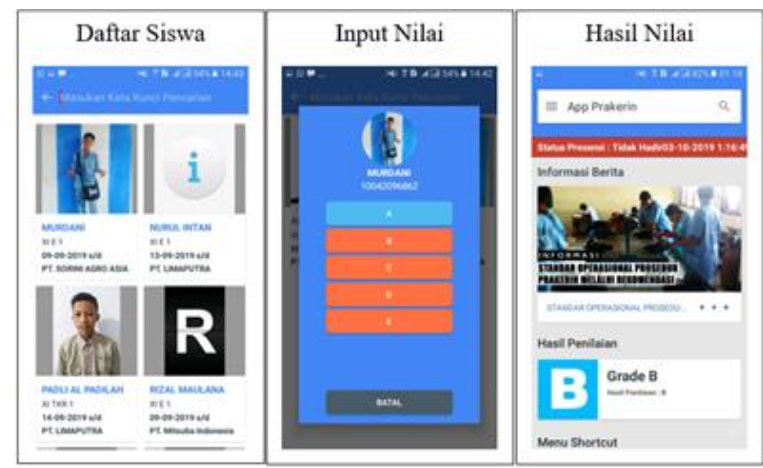

Gambar 22. Tampilan Menu Nilai

Penilaian dilakukan oleh guru dan juga pembimbing industri setelah memantau kinerja keseharian siswa melalui pelaksanaan kerja, presensi, catatan kegiatan, dan pengumpulan laporan. Kedua User tersebut masing-masing berhak memberikan penilaian sesuai hasil evaluasi yang berbeda. Grade nilai mulai dari range $\mathrm{A}, \mathrm{B}, \mathrm{C}, \mathrm{D} \& \mathrm{E}$ yang nantinya guru dan pembimbing industri menilai melalui fitur ini. Kemudian pada User siswa akan tampil hasil kombinasi penilaian dari keduanya pada menu utama setelah login.

\section{SIMPULAN}

Sistem informasi prakerin berbasis Android dapat membantu proses praktek kerja industri di Jurusan Elektronika Industri SMK Negeri 1 Cikande. Proses untuk mendapatkan informasi jauh lebih mudah dan cepat dilakukan dengan cara menggunakan Smartphone. Pengembangan sistem informasi prakerin berbasis Android ini menggunakan metode penelitian $(\mathrm{R} \& \mathrm{D})$ dengan model pengembangan Waterfall. Hasil kelayakan dari ahli media diperoleh persentase sebesar $93,75 \%$ sehingga dinyatakan "sangat layak", penilaian dari guru sebagai pengguna sebesar $78,7 \%$ dinyatakan 'layak' dan penilian dari siswa sebesar 79,86\% dinyatakan 'layak'. 


\section{DAFTAR RUJUKAN}

Andayani, D. D., \& Dirawan, G. D. 2019. Pengembangan Sistem Informasi Publikasi Ilmiah Menggunakan Model System Development Life Cycle Berbasis Dynamic Web. In Seminar Nasional LP2M UNM, 512-517.

Arifin, M. 2014. Analisa dan Perancangan Sistem Informasi Praktek Kerja Lapangan pada Instansi/Perusahaan. Jurnal SIMETRIS, 49-56.

Binus. (2018, Januari 4). Library Binus. Retrieved from Binus University: http://library.binus.ac.id/eColls/eThesisd oc/Bab2HTML/2007200217IFBab2/page 11.html

Budiman, H. 2017. Peran Teknologi Informasi dan Komunikasi Dalam Pendidikan. AlTadzkiyyah: Jurnal Pendidikan Islam , 31-43.

Dini, B. A., \& Agmawarnida. 2018. Implementasi Waterfall Method Pada Aplikasi Penerimaan Peserta Didik Baru Berbasis Web Dengan Dukungan SMS Gateway di SMPIT Insan Kamil. Jurnal Informatika SIMANTIK, 36-42.

Febriyanti, S. R., \& Melian, L. 2013. Rancang Bangun Sistem Informasi Prakerin (Studi Kasus : Puncak Pass Resort). FTIK UNIKOM, 49-55.

Gani, A. G. 2016. e-Learning Sebagai Peran Teknologi Informasi Dalam Modernisasi Pendidikan. Sistem Informasi Universitas Suryadarma, 1-19.

Ispandi. 2019. Membangun Sistem Informasi Perpustakaan Digital Berbasis Web. Jurnal Pendidikan Teknologi dan Kejuruan, 225-235.

Manfaat, B. 2018. Analisis Data Kuantitatif. IAIN Syekh Nurjati Cirebon.

Nuari, N. 2014. Perancangan Aplikasi Layanan Mobile Informasi Administrasi Akademik Berbasis Android Menggunakan Webservice (Studi Kasus Reg. B Universitas Tanjungpura).
JUSTIN (Jurnal Sistem dan Teknologi Informasi), 1-6.

Nugroho, V. A., Irawan, P. L., \& Prilianti, K. R. 2016. Rancang Bangun Aplikasi Penjadwalan Bimbingan PKL dan Skripsi Berbasis Android. SMATIKA Jurnal (STIKI Informatika Jurnal), 15-20.

Pradana, A. G., \& Nita, S. 2019. Rancang Bangun Game Edukasi "AMUDRA"Alat Musik Daerah Berbasis Android. In Prosiding Seminar Nasional Teknologi Informasi dan Komunikasi (SENATIK), 49-53.

Pressman, R. S. 2002. Rekayasa Perangkat Lunak: Pendekatan Praktis. Yogyakarta: ANDI.

Pressman, R. S. 2010. Software Engineering: A Practitioner's Approach, Seventh Edition. New York: McGraw Hill Companies.

Ristekdikti. (2018, Januari 30). "Era Revolusi Industri 4.0, Saatnya Generasi Millennial Menjadi Dosen Masa Depan". Retrieved from Sumber Daya Ristekdikti:

http://sumberdaya.ristekdikti.go.id/inde x.php/2018/01/30/era-revolusi-industri4-0-saatnya-generasi-millennialmenjadi-dosen-masa-depan/

Sukir, Nurkhamid, \& Nurdiyansyah. 2019. Kelayakan E-Modul Berbasis Android Untuk Mendukung Pembelajaran Aplikasi PLC Sebagai Pengendali Mesin Pengisi dan Penutup Botol Otomatis di SMK . Jurnal Edukasi Elektro, 88-98.

Susafa'ati. 2019. Implementasi Model Waterfall Pada Sistem Informasi Pengiriman Barang Berbasis Web. Jurnal Teknik Komputer Amik BSI, 271-276.

Yamasari, Y., Asmunin, \& Kurniawan, I. F. 2015. Pengembangan Sistem Informasi Manajemen Skripsi di Jurusan Teknik Elektro, FT UNESA. Jurnal Manajemen Informatika, 1-10. 